\title{
PEGADAIAN SYARIAH : PENERAPAN AKAD RAHN PADA PEGADAIAN SYARIAH
}

\author{
Nuroh Yuniwati'1), Emilia Dwi Lestari'2), Anis Alfiqoh ${ }^{3)}$ \\ 1).2).3)IAIN Pekalongan \\ 1)nurohyuniwati09@gmail.com, 2)emilialestari468@gmail.com, 3) anisalfiqoh06@gmail.com
}

\begin{abstract}
Abstrak. Lembaga Keuangan Syariah di Indonesia menerapkan berbagai macam produk dan akad dalam menjalankan kegiatan usahanya, salah satu produknya adalah akad rahn yang ada di Pegadaian Syariah, adanya kebebasan untuk mendesain bentuk akad akan memberikan keberagaman produk, Namun demikian analisis fiqh dilakukan untuk menghindari hal- hal yang dilarang, mrngingat salah satu kaidah dalam ushul fiqh adalah pada dasarnya semua transaksi diperbolehkan kecuali ada dalil yang jelas melarangnya. Berdasarkan rukun akad rahn secara praktik mulai dari marhun, marhun bih, shighah, dan 'aqidaini sudah sesuai dengan dengan teori syariah, tetapi masih ada beberapa hal yang harus diperjelas untuk mendapatkan praktik yang benar secara teori syariah. Yaitu tentang pemanfaatan barang gadai yang belum dijelaskan secara rinci tentang pemanfaatan dari pihak rahin maupun dari pihak murtahin.
\end{abstract}

Kata Kunci : Akad Rahn, Pegadaian Syariah

\begin{abstract}
Islamic Financial Institutions in Indonesia apply a variety of products and contracts in carrying out their business activities, one of the products is the rahn contract at the Sharia Pawnshop, the freedom to design the form of the contract will provide a variety of products, however fiqh analysis is carried out to avoid things that prohibited, considering that one of the rules in ushul fiqh is that basically all transactions are allowed unless there is a clear argument forbidding it. Based on the pillars of the rahn contract in practice, starting from marhun, marhun bih, shighah, and 'aqida this is in accordance with sharia theory, but there are still some things that must be clarified to get the correct practice in sharia theory. That is about the use of pawned goods that have not been explained in detail about the use of the rahin and the murtahin.
\end{abstract}

Keywords: Rahn contract, Sharia pawnshop

\section{PENDAHULUAN}

\section{Latar belakang}

Perkembangan sistem keuangan syariah ditandai dengan didirikannya berbagai lembaga keuangan syariah dan diterbitkannya berbagai instrumen keuangan berbasis syariah. Lembaga keuangan syariah secara esensial berbeda dengan lembaga keuangan konvensional, baik dalam tujuan, mekanisme, kekuasaan, ruang lingkup, serta tanggung jawabnya. Setiap institusi dalam lembaga keuangan syariah menjadi bagian integral dari sistem keuangan syariah. 
Lembaga keuangan syariah bertujuan membantu mencapai tujuan sosio-ekonomi masyarakat Islam.

Lembaga keuangan berperan penting dalam pengembangan dan pertumbuhan masyarakat industri modern. Produksi berskala besar dengan kebutuhan investasi yang membutuhkan modal yang besar tidak mungkin dipenuhi tanpa bantuan para pengusaha untuk mendapatkan tambahan modalnya melalui mekanisme kredit dan menjadi tumpuan investasi mekanisme saving. ${ }^{1}$ Kemudian pada setiap perusahaan lembaga keungan adalah setiiap bidang usahanya yang hanya bergerak dibidang keuangan. Lembaga keuangan dibagi menjadi dua yaitu lembaga keuangan bank dan lembaga keuangan bukan bank. Lembaga keuangan bank adalah Bank Sentral, Bank Umum, dan BPR, sedangkan lembaga keuangan bukan bank yaitu asuransi, leasing, anjak piutang (factoring), modal ventura, pegadaian, dana pensiun, pasar modal, reksa dana, kartu kredit dan lembaga pembiayaan konsumen. Pegadaian merupakan Salah satu solusi bagi masyarakat, ketika seseorang membutuhkan dana dalam kondisi yangmendesak dan cepat, sedangkan yang bersangkutan tidak memiliki dana cash atau tabungan maka pendanaan pihak ketiga menjadialternative pemecahannya. Saat mengakses jasa perbankan bagi beberapa masyarakat akan menghadapi administrasi dan persyaratanyang rumit, sehingga sebagian orang akan datang pada rentenir, meskidengan bunga yang cukup tinggi. Bagi sebagian orang memilikiharta yang bisa dijadikan agunan, maka pegadaian pilihannya, sebabtransaksi gadai paling aman, legal dan terlembaga. Salah satu produk lembaga keuangan Syariah (LKS) adalah "pembiayaan" yang dalam hukum Islam (baca: fikih) kepentingan kreditur itu sangat dijaga dan diperhatikan. Oleh karena itu, ia dibolehkan meminta 'barang' dari debitur sebagai jaminan utangnya. Dalam dunia finansial, barang jaminan ini biasa dikenal dengan objek jaminan (colleteral) atau barang gadai (marhun) dalam Gadai Syariah. Gadai sebagai salah satukategori dari perjanjian utang-piutang, untuk suatu kepercayaan dari kreditur, maka debitur menggadaikan barangnya sebagai jaminan terhadap utangnya itu. Barang jaminan tetap milik orang yang menggadaikan, namun dikuasai oleh penerima gadai.

\section{Rumusan masalah dan tujuan}

Pegadaian Syariah : Penerapan Akad ar-Rahn di dalam Pegadaian Syariah, dalam penelitian ini akan dibahas mengenai bagaimana penerapan akad ar-Rahn pada Pegadaian Syariah yang merupakan lembaga keuangan syariah. Dalam pembentukan Pegadaian Syariah selain karena tuntutan idealisme juga disebabkan keberhasilan terlembaganya bank,

${ }^{1}$ Muhammad Ridwan, Manajemen Baitul Maal Wa Tamwil (BMT), UII Press, Yogyakarta, 2004, hlm. 51 
BMT, BPR dan asuransi syariah, pegadaian mendapat perhatian untuk dibentuk di bawah naungan suatu lembaga tersendiri. Atas dasar evaluasi dari perkembangan rahnsebagai produk perbankan syariah yang belum begitu baik, disebabkan oleh terbatasnya keberadaan komponen pendukung produk rahn seperti, sumber daya penafsir, alat untuk menafsir, dan gudang penyimpanan barang jaminan, bank tidak mampu memfasilitasi keberadaan rahn, tetapi rahn sangat dibutuhkan masyarakat. Oleh sebab itu, masyarakat diharuskan untuk mengerti dan memahami mengenai penerapan akad rahn pada pegadaian syariah itu sendiri. Dari permasalahan tersebut maka munculah rumusan masalah yang berkaitan dengan hal tersebut yaitu Bagaimana Penerapan Akad Rahn pada Pegadaian Syariah. Selanjutnya dari permasalahan yang muncul tersebut bertujuan agar dapat menjawab serta penjelasan mengenai penerapannya. Tujuan pokok berdirinya pegadainya syariah adalah untuk mewujudkan kemaslahatan umat dan saling tolong-menolong. Dengan adanya pegadaian syariah maka dapat membertantas rentenir, praktek gadai gelap yang sangat memberatkan dan membebani masyarakat kecil.

\section{KAJIAN PUSTAKA}

\section{Akad Rahn}

\section{a. Definisi Akad Rahn}

Gadai atau al-rahn secara bahas adapat diartikan dengan (al-stubut, al habs) yaitu penetapan dan penahanan. Istilah hokum positif di Indonesia rahn adalah apa yang disebut barang jaminan, agunan, rungguhan, cagar atau cagaran, dan tanggungan. Azhar Basyir memaknai Rahn (gadai) sebagai perbuatan menjadikan suatu benda yang bernilai menurut pandangan syara' sebagai tanggungan uang, dimana adanya benda yang menjadi tanggungan itu diseluruh atau sebagian utang dapat diterima. Dalam hukum adat gadai diartikan sebagai menyerahkan tanah untuk menerima sejumlah uang secara tunai, dengan ketentuan si penjual (penggadai) tetap berhak atas pengembalian tanahnya dengan jalan menebusnya kembali.

Al-rahn adalah menahan salah satu harta milik si peminjam atas pinjaman yang diterimanya. Barang yang ditahan tersebut memiliki nilai ekonomis. Dengan demikian pihak yang menahan memperoleh jaminan untuk dapat mengambil kembali seluruh atau sebagian piutangnya. Secara sederhana dapat dijelaskan bahwa rahn adalah semacam jaminan hutang atau gadai. Pemilik barang gadai disebut rahin dan orang yang menghutangkan yaitu orang yang mengambil barang tersebut serta menahannya disebut murhatin, sedangkan barang yang digadaikan disebut rahn. 
Jadi pada intinya pelaksanaan gadai adalah suatu kegiatan hutang piutang antara kedua belah pihak dengan menjadikan suatu barang yang berharga atau bernilai sebagai jaminannya.

\section{b. Dasar Hukum ar-Rahn}

1) Al-Qur'an

Para ulama fiqh mengemukakan bahwa akad Rahn dibolehkan dalam islam berdasarkan al-Qur'an dan sunnah Rasul dalam surat Al-Baqarah ayat 283 Allah berfirman :

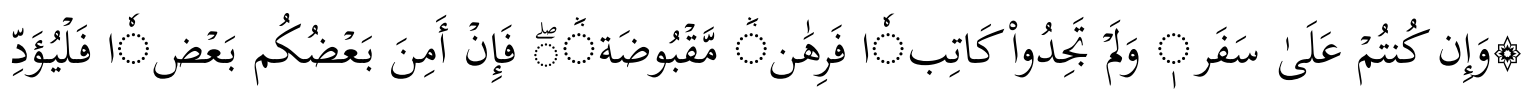

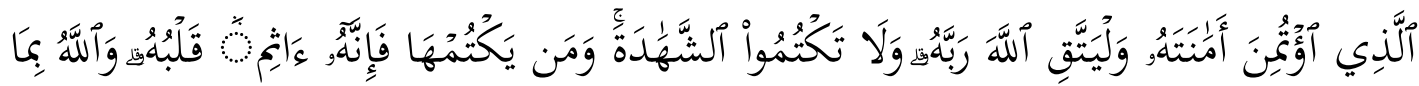

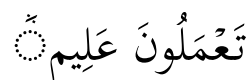

Artinya : "jika kamu dalam perjalanan (dan bermuamalah tidak secara tunai) sedang kamu tidak memperoleh seorang penulis, maka hendaklah ada barang tanggngan yang dipegang (oleh yang berpiutang), akan tetapi jika sebagian kamu mempercayai sebagian yang lain, maka hendaklah yang dipercayai itu menunaikan amanatnya (hutangnya) dan hendakhan ia bertaqwa kepada Allah Tuhannya; dan janganlah kamu (para saksi) menyembunyikan kesaksiannya, dan Barangsiapa yang menyembunyikannya, maka sesungguhnya ia adalah orang yang berdosa hatinya; dan Allah Maha Mengetahui apa yang kmau kerjakan. Barang tanggungan itu diadakan bila satu sama lain tidak percaya mempercayai." (QS. Al-Baqarah : 283)

Para ulama fiqh sepakat bahwa ar-rahn boleh dilakukan dalam perjalanan dan dalam keadaan hadir ditempay, asal barang jaminan itu bisa langsung dipegang/dikuasai secara hokum oleh si piutang. Maksudnya, karena tidak semua barang jaminan bisa dipegang/dikuasai oleh si pemberi piutang secara langsung, maka paling tidak ada semacam pegangan yang dapat menjamin bahwa barang dalam status al-Marhun (menjadi jaminan hutang). Misalnya apabila barang jaminan itu berbentuk sebidang tanag, maka yang dikuasai adalah surat jaminan tanah itu.

2) Hadist

Di dalam sebuah Hadist Riwayat Bukhari, kitab Ar-Rahn dikatakan bahwa :

Artinya : "dari Aisyah, sesungguhnya Nabi SAW membeli makanan secara tudak tunai dari seorang Yhudi dengan menggadaikan baju besinya". (H.R. Bukhari)

Menurut kesepakatan pakar fiqh, persitiwa Rasulullah SAW me-rahn- kan beju besinya itu, adalah kasus ar-rahn pertama dalam Islam dan dilakukan sendiri oleh Rasulullah SAW. Berdasrkan ayat dan hadist diatas, para ulama fiqh sepakat mengatakan bahwa akad ar-rahn itu dibolehkan, karena banyak kemaslahatan yang terkandung di dalamnya dalam rangkan hubungan antar sesama manusia. ${ }^{2}$

\footnotetext{
${ }^{2}$ Ibnu Qudamah, “Al-Mugni”, (Riyadh : Maktabah ar-Riyadh al-Haditsah), Jilid IV, hlm. 337
} 
3) Ijma

Para ulama telah menyepakati bahwa al-qardh boleh dilakukan. Kesepakatan ulama ini didasari tabiat manusia yang tidak bisa hidup tanpa petolongan dan bantuan saudaranya. Tidak ada seorangpun yang memiliki segala barang yang ia butuhkan oleh karena itu pinjam meminjam telah menjadi satu bagian dari kehidupan di dunia ini. Islam adalah agama yang sangat memperhatikan segenap kebutuhan umatnya. Disamping itu, berdasarka Fatwa Dewan Syariah Nasional No. 25/DSN- MUI/III/2002, tanggal 26 Juni 2002 dinyatakan bahwa, pinjaman dengan menggadaikan barang sebagai jaminan hutang dalam bentuk rahn dibolehkan. Jumhur ulama berpendapat bahwa rahn disyariatkan pada waktu tidak bepergian maupun pada waktu bepergian. ${ }^{3}$

\section{c. Rukun dan Syarat ar-Rahn}

Dalam melaksanakan suatu perikatan terdapat rukun dan syarat gadai yang harus dipenuhi. Secara bahasa rukun adalah yang harus dipenuhi untuk sahnya suatu pekerjaan. Sedangkan syarat adalah ketentuan (peraturan, petunjuk) yang harus dipindahkan dan dilakukan. Adapun rukun rahn adalah :

1) Orang yang berakad, mereka adalah dua orang yang berakad (Rahin) dan murtahin (pemilik piutang yang menguasai”“'harta gadai sebagai barang jaminan hutangnya).

2) Ma'qud Alahi, yaitu harta benda yang menjadi barang jaminan serta hutang sebagai pinjaman rahin

3) Shighat, yaitu lafadz yang terdiri dari ijab dan qabul dari" “kedua pihak yang melakukan transaksi gadai. ${ }^{4}$

Adapun syarat -syarat bagi sahihnya suatu akad gadai adalah sebagai berikut:

1) Syarat-syarat yang harus dipenuhi oleh dua orang yang berakad adalah fahamm dengan akad yang dilaksanakan, yang berarti sudah baligh, berakahl, dan tidak gila

2) Syarat bagi barang jaminan adalah hendaknya barang tersebut ada ketika akad berlangsung, namun boleh juga dengan menunjukkan bukti kepemilikannya seperti surat-surat tanah, kendaraan, dll. Dan barang gadai tersebut dapat dipegang/dikuasai oleh murtahin atau wakilnya. Selain itu, barang gadai tersebut hendaknya adalah barang yang bernilai harta dalam pandangan Islam, karena itu tidak sah menggadaikan barang-barang haram seperti khamr minuman keras). Demikian juga

3 Muhammad Sholekul Hadi, "Pegadaian Syariah", (Jakarta : Salemba Diniyah, 2003), hlm. 52

${ }^{4}$ Abdurrahman Misno, "Gadai dalam Syari'at Islam”, (Bogor : STAI Al-Hidayah Bogor), hlm. 30 
hendaknya barang tersebut harus utuh bukan hutang, barang tersebut adalah barang yang didagangka atau dipinjamkan, barang warisan, dan barang tersebut hendaknya bukan barang yang cepat rusak

3) Syarat pada sighat (lafadz), hendaknya lafadz dalam ijab qabul itu jelas dan paham dipahami oleh pihak yang berakad, Ulama Hanafiyah mensyaratkan bahwa sighat gadai hendaknya tidak terkait dengan sesuatu syarat yang tidak dilakukan diwaktu yang akan datang. Hal ini karena akad gadai mirip dengan akad jual beli. Adapun lafadz gadai dapat derupa ucapan "aku gadaikan harta bendaku" dll.“Boleh juga tanpa lafadz tertentu namun tetap mengindikasikan akad gadai

4) Syarat Marhin Bih, marhun bih adalah hak yang diberikan oleh murtahin kepada rahin ketika terjadi akad gadai, para ulama selain Hanafiyah mensyaratkan bahwa marhun bih hendaknya adalah berupa hutang baik" "hutang ataupun barang, dan dapat dibayarkan (dikembalikan) serta benda tersebut milik murtahin. ${ }^{5}$

\section{Pegadaian Syariah}

Pegadaian merupakan lembaga pembiayaan atau perkreditan dengan sistem gadai, PT Pegadaian merupakan salah satu perusahaan dibawah naungan Kementrian BUMN. Tugas pokok PT Pegadaian adalah menjembatani kebutuhan dana masyarakat dengan pemberian uang pinjaman berdasarkan hukum gadai. Bersamaan dengan berkembangnya produk syariah di Indonesia, pada tahun 2003 sektor pegadaian juga mendirikan pegadaian syariah dengan membentuk Unit Layanan Gadai Syariah (ULGS), yang dalam pelaksanaannya berpegang kepada prinsip syariah. Hingga kini Pegadaian Syariah masih menginduk pada PT Pegadaian dan direncanakan spin off. Pada tahun 2019. Konsep operasi pegadaian syariah mengacu pada sistem administrasi modern dengan asas rasionalitas, efesiensi, dan efektivitas dengan nilai Islam. Fungsi operasi pegadaian syariah dijalankan di kantor-kantor cabang pegadaian syariah atau ULGS sebagai satu unit organisasi di bawah binaan Divisi Usaha Lain PT Pegadaian, dan merupakan unit bisnis mandiri yang secara struktural terpisah dari usaha gadai konvensional. Unit Usaha Layanan Syariah cabang Dewi Sartika di Jakarta adalah pegadaian syariah pertama, berdiri pada Januari tahun 2003. Dan selanjutnya pendirian ULGS di Surabaya, Makasar, Semarang, Surakarta dan Yogyakarta hingga bulan September 2003, di tahun yang sama pula, 4 kantor cabang pegadaian di Aceh di konversi menjadi kantor Pegadaian Syariah. ${ }^{6}$

${ }^{5}$ Rahnat Syafe'I, "Fiqh Muamalah" (Bandung : Setia Pustaka, 2004), hlm. 164

${ }^{6}$ Arif Efendi, "Gadai Syariah dalam Prespektif Ekonomi Islam Studi tentang Layanan Syariah Rahn pada PT Pegadaian Persero", Jurnal Wahana Akademika, Vol. 15 No. 01, April 2013, Hlm. 38. 
Tujuan pokok berdirinya pegadainya syariah adalah untuk mewujudkan kemaslahatan umat dan saling tolong-menolong. Dengan adanya pegadaian syariah maka dapat membertantas rentenir, praktek gadai gelap yang sangat memberatkan dan membebani masyarakat kecil. Alasan yang melatar belakangi diperbolehkannya pegadaian syariah itu karena sifat social, dapat membentu meringankan beban masyarakat menengah kebawah yang dalam kesehariannya masih bersifat konsumtif, dan tujuannya pula untuk mewujudkan kemaslahatan bagi umat. Namun dalam kegiatan operasionalnya pegadaian syariah masih lebih banyak dimanfaatkan oleh masyarakat berpendapatan golonga menengah keatas, yang bersifat komersil produktif. Hal ini dapat dilihat dari besarnya marhun berupa emas dan berlian yang banyak diterima gadai. ${ }^{7}$

\section{METODE PENELITIAN}

Pada penelitian ini menggunakan jenis data sekunder, data sekunder adalah jenis data yang diambil seorang peneliti untuk mendukung sebuah penelitian secara ilmiah dengan melakukan rangkaian studi pustakan melalui beberapa media seperti jurnal, majalah, internet, karya ilmiah, artikel dan sumber lain yang diperlukan. Pengumpulan data yang dibutuhkan pada penelitian ini menggunakan teknik dengan beberapa metode studi pustaka, metode ini digunakan dengan cara menemukan berbagai dasar - dasar teori yang memiliki hubungan tentang penarapan yang digunakan pada Akad Rahn dalam Pegadaian Syariah. Data yang dihasilkan pada saat melakukan penelitian adalah data yang bersifat deskriptif. Data yang berasal dari lisan orang-orang atau dapat juga berupa tulisan kata - kata serta hasil pengamatan dari suatu keadaan.

\section{HASIL DAN PEMBAHASAN}

\section{Penerapan Akad Rahn pada Pegadaian Syariah}

Dalam mekanisme operasional Pegadaian Syariah melalui akad rahn adalah dengan masyarakat menyerahkan barang bergerak dan kemudian pegadaian menyimpan dan merawat barang tersebut di tempat yang telah disediakan oleh pegadaian. Akibat dari proses penyimpanan adalah timbulnya biaya-biaya yang meliputi nilai dari tempat penyimpanan, biaya perawatan dan keseluruhan proses kegiatan. Atas dasar ini dibenarkan bagi pegadaian mengenakan biaya sewa bagi nasabah sesuai jumlah yang disepakati oleh kedua belah pihak. Pegadaian Syariah akan mendapatkan keuntungan hanya dari

${ }^{7}$ Rais Sasli, "Pegadaian Syariah : Konsep dan Sistem Operasinalnya”, (Jakarta : UI Press, 2008), hlm.36 
beasewa tempat yang diambil bukan tambahan berupa bunga atau sewa modal yang diperhitungkan dari uang pinjaman. Dalam hal ini, Akad rahn yang dimaksudkan adalah produk pembiayaan rahn yang ada di Pegadaian Syariah.

Transaksi gadai menurut syariah harus memenuhi rukun dan syaratnya. Pada dasarnya pegadaian syariah berjalan atas dua akad transaksi, yaitu akad Rahn dan akad Ijarah. Kedua akad akan ditandatangani sekaligus pada saat nasabah (rahn) menyerahkan hartanya. Nasabah (rahn) mengembalikan utang itu sesuai dengan jumlah utangnya. Akad ijarah, nasabah dibebani membayar ujrah (bea penyimpanan) kepada pegadaian.

Jenis barang yang dapat diterima sebagai barang jaminan pada prinsipnya adalah barang bergerak, antara lain: ${ }^{8}$

a. Barang-barang perhiasan, yaitu semua perhiasan yang dibuat dari emas, perhiasan perak, platina, baik yang berhiaskan intan, mutiara.

b. Barang-barang elektronik: laptop, TV, kulkas, radio, tape recorder, vcd/dvd, radio kaset.

c. Kendaraan: Sepeda, Sepeda Motor, Mobil. d. Barang-barang rumah tangga

d. Mesin: mesin jahit, mesin motor kapal

e. Barang-barang lain yang dianggap bernilai seperti surat-surat berharga baik dalam bentuk saham, obligasi, maupun surat-surat berharga lainnya.

Pembiayaan rahn di pegadaian syariah adalah solusi tepat kebutuhan dana cepat yang sesuai syariah. Prosesnya cepat hanya dalam waktu 15 menit dana cair dan aman penyimpanannya. Jaminan berupa barang perhiasan, elektronik ataukendaraan bermotor dan barang bergerak lainnya. Keunggulan produk ini adalah:

a. Layanan rahn ada di outlet pegadaian syariah seluruh Indonesia b. Prosedur pengajuannya sangat mudah

b. Proses peminjaman sangat cepat hanya 15 menit

c. Pinjaman (Marhun Bih) mulai dari 50 ribu rupiah sampai 500 juta rupiah atau lebih

d. Jangka waktu pinjaman maksimal 4 bulan atau 120 hari dan dapat diperpanjang berkali-kali dengan cara membayar ijarah saja atau mengangsur sebagian uang pinjaman

f. Pelunasan dapat dilakukan sewaktu-waktu dengan perhitungan ijarah selama masa pinjaman

g. Proses pinjaman tanpa perlu membuka rekening 
h. Nasabah menerima pinjaman dalam bentuk tunai atau di transfer ke rekening

i. Barang jaminan tersimpan aman di pegadaian.

Model bisnis gadai syariah yang mudah dan cepat di Pegadaian Syariah adalah sebagai berikut:

a. Nasabah datang membawa (Marhun) agunan,

b. Marhun ditaksir oleh Penaksir dari Pegadaian Syariah,

c. Marhun bih diterima oleh nasabah tunai atau ditransfer.

Dengan persyaratan, yang cukup mudah yaitu :

a. Fotokopi KTP atau kartu indentitas resmi lainnya b. Memiliki barang jaminan

b. Untuk kendaraan bermotor membawa BPKB dan STNK asli d. Nasabah menandatangani Surat Bukti Rahn (SBR).

Pegadaian sebagai lembaga keuangan tidak diperkenankan menghimpun dana secara langsung dari masyarakat dalam bentuk simpanan. Untuk memenuhi kebutuhan dananya, PT Pegadaian memiliki sumber-sumber dana sebagai berikut: Modal sendiri, Penyertaan modal pemerintah, Pinjaman jangka pendek dari perbankan, Pinjaman jangka panjang yang berasal dari kredit lunak Bank Indonesia, dari masyarakat melalui penerbitan obligasi. ${ }^{9}$

Aspek syariah tidak hanya menyentuh bagian operasionalnya saja, pembiayaan kegiatan dan pendanaan bagi nasabah, harus diperoleh dari sumber yang benar-benar terbebas dari unsur riba. Seluruh kegiatan pegadaian syariah termasuk dana yang kemudian disalurkan kepada nasabah, murni berasal dari modal sendiri ditambah dana pihak ketiga dari sumber yang dapat dipertanggungjawabkan. Pegadaian telah melakukan kerja sama dengan Bank Muamalat sebagai fundernya, kedepan bank syariah juga akan melakukan kerja sama dengan lembaga keuangan syariah lain untuk memback-up modal kerja. Apabila nasabah belum bisa melunasi utangnya dan kewajibannya, maka gadai itu bisa diperpanjang. Nasabah cukup membayar biaya simpan dan biaya administrasi. Sedangkan jika rahintidak mampu melunasi utang dan kewajibannya, dan juga tidak memperpanjang gadainya, maka setelah tenggat waktu tertentu atau setelah murtahinmemberi peringatan, maka kreditur bisa mengeksekusi harta yang digadaikan dan selanjutnya akan dilakukan pelelangan.

\section{Analisis Akad Rahn}

Akad rahn adalah perjanjian yang menjadikan barang berharga sebagai jaminan utang hingga pihak yang bersangkutan bisa mengembalikan utang. Dengan begitu jaminan tersebut berkaitan erat dengan utang piutang. Rukun rahn adalah marhun, marhun bih,

${ }_{9}^{9}$ Dahlan Siamat, Manajemen Lembaga Keuangan, (Jakarta: Lembaga Penerbit Fakultas Ekonomi Universitas Indonesia, 2004), Edisi Keempat, Hlm. 504-505 
shighah, 'aqidaini(rahin dan murtahin). Sedangkan syarat rahnadalah berakal, baligh, dan marhun ada pada saat akad dan marhun diterima oleh murtahinatau wakilnya.

Mekanisme operasional akad rahn di Pegadaian Syariah adalah masyarakat menyerahkan barang bergerak dan kemudian pegadaian menyimpan dan merawat barang tersebut di tempat yang telah disediakan oleh pegadaian. Dari proses penyimpanan, timbul biaya yang meliputi nilai dari tempat penyimpanan, perawatan dan keseluruhan proses kegiatan. Atas dasar ini, menurut pegadaian syariah dibenarkan bagi pegadaian mengenakan biaya sewa bagi nasabah sesuai jumlah yang disepakati oleh kedua belah pihak. Pegadaian Syariah akan mendapatkan keuntungan hanya dari beasewa tempat yang diambil bukan tambahan berupa bunga atau sewa modal yang diperhitungkan dari uang pinjaman. Akad rahn yang dimaksudkan adalah produk pembiayaan rahn yang ada di Pegadaian Syariah. 


\section{DAFTAR PUSTAKA}

Arif Efendi, 2013, Gadai Syariah dalam Prespektif Ekonomi Islam Studi tentang Layanan Syariah Rahn pada PT Pegadaian Persero, Jurnal Wahana Akademika, Vol. 15 No. 01, April.

Dahlan Siamat, 2004, Manajemen Lembaga Keuangan, Jakarta: Lembaga Penerbit Fakultas Ekonomi Universitas Indonesia.

Kasmir, 2008, Bank dan Lembaga Keuangan Lainnya, Jakarta: PT Rajagrafindo. Rachmat Syafe'i, 2001, Fiqih Muamalat, Bandung: CV Pustaka Setia.

Sasli Rais, 2008, Pegadaian Syariah: Konsep dan Sistem Operasional (Suatu Kajian Kontemporer), UI Press, Jakarta. 